\title{
Gasoline Particle Filter Development
}

\author{
Christine Lambert $^{1} \cdot$ Timothy Chanko $^{1} \cdot$ Douglas Dobson $^{1} \cdot$ Xin Liu $^{1} \cdot$ James Pakko $^{1}$
}

Received: 23 August 2016 / Revised: 15 November 2016 / Accepted: 21 November 2016/Published online: 18 February 2017

(C) The Author(s) 2017

\begin{abstract}
Gasoline particle filter (GPF) development includes optimization of multiple, competing targets: low backpressure, high clean filtration, acceptable strength, high oxygen storage capacity, small size, and low cost. A three-way catalyst + GPF system needs to meet targets for hydrocarbons, carbon monoxide, and nitrogen oxides in addition to particle mass and/or particle number. GPFs behave differently than diesel particle filters (DPFs) in terms of regeneration and ash loading behavior due to vastly different operating conditions. In a relatively clean exhaust condition on GDI relative to diesel, an empty GPF can have filtration efficiencies on the order of $60 \%$. This was improved to $80-90 \%$ with a small amount of soot and/or ash on the filter walls, or higher catalyst washcoat loading. In the course of this work, models were developed to predict backpressure, filtration, and chemical performance.
\end{abstract}

Keywords Particle number · Particle mass · Particle filtration · Gasoline particle filter · Particulate number . Particulate mass $\cdot$ Particulate filtration · Gasoline particulate filter

\section{Introduction}

Direct injected gasoline (GDI) engines can create significant amounts of soot under certain operating conditions such as cold start and high load. California LEVIII and US Tier 3 will

Christine Lambert

clamber9@ford.com

1 Ford Research and Innovation Center, MD 3179 RIC, PO Box 2053, Dearborn, MI 48121, USA require a tailpipe particulate matter (PM) maximum of $3 \mathrm{mg} /$ $\mathrm{mi}$, down from the current $10 \mathrm{mg} / \mathrm{mi}$. Phase-in for lower PM will occur in the 2017-2021 model years. Euro 6 particle number $(\mathrm{PN})$ standards for DI vehicles are currently at $6 \times 10^{12}$ particles $/ \mathrm{km}$ (stage 1) and become $90 \%$ lower at $6 \times 10^{11}$ particles $/ \mathrm{km}$ in September 2017 (stage 2). New tests like Worldwide Harmonized Light Vehicles Test Procedure (WLTP) and Real Driving Emissions (RDE) will cover more driving conditions than on the older NEDC (New European Driving Cycle). Wall flow ceramic filters are one way to remove exhaust PM and PN, and have well-known canning and assembly processes for automotive exhaust treatment. The filter may be used with or without a catalytic washcoat, and when applied to gasoline vehicles is called gasoline particle filter (GPF). In a relatively clean exhaust condition on GDI relative to diesel, a typical GPF with a small amount of soot and/or ash on the filter can offer filtration efficiencies on the order of 70-80\% [1] because most likely there will not be a soot cake present that would yield filtration efficiencies of $99+\%$ like on a diesel vehicle.

It is not trivial to fit a filter into a gasoline exhaust system that already contains one or more three-way catalysts (TWCs) to control hydrocarbons $(\mathrm{HC})$, carbon monoxide $(\mathrm{CO})$, and nitrogen oxides (NOx). Often there is room underbody, downstream of the TWC(s), and the filter may be used without catalytic coating because it is not needed to meet emissions; however, the filter will be colder and will tend to trap more soot, possibly needing active regenerations. On the other hand, some vehicles have very little ground clearance, and the filter must go in a location closer to the engine. If there are two existing TWCs, the filter may replace the second catalyst and would need to have catalytic coating itself to preserve emission control at higher speed/load conditions. The closer location is warmer and may tend toward lower soot loadings, because modern gasoline vehicles, while mostly 
operated at stoichiometric or even slightly rich air/fuel ratios, have fuel cuts during decelerations that provide oxygen to passively burn soot at favorable temperatures. Whatever system configuration is chosen, it should meet requirements for packaging, emissions ( $\mathrm{HC}, \mathrm{CO}, \mathrm{NOx}, \mathrm{PM}$, and/or PN), cost, onboard diagnostics (OBD), and backpressure.

\section{Experimental}

Coated and uncoated filter cores, usually 1" diameter and 3" long, were tested for performance in laboratory reactors. GPF samples were characterized for green filtration efficiency, soot and ash loaded filtration efficiency, permeability, physical dimensions, and mechanical properties. A summary of typical physical properties are in Table 1. Filtration efficiency and backpressure of full-size ceramic filters was performed using a 2.0-L gasoline turbocharged direct injection (GTDI) engine in a dynamometer cell at the Ford Research and Innovation Center in Dearborn, MI. The cell was equipped with two Dekati Mass Monitors (DMMs) that measured PM on a mass basis. A correlation was found previously at Ford for PM and PN during extensive GDI vehicle testing [2], where $2 \times 10^{12}$ / $\mathrm{km} \mathrm{PN}$ is approximately equal to $1 \mathrm{mg} / \mathrm{km} \mathrm{PM}$.

Permeability was derived from the backpressure measured on a cold flow bench with either a filter core or a homemade wafer of the filter wall itself cut from a monolith. Full-size filters were also flowed at room temperature at Ford's Powertrain Fuel Systems Lab (PFSL) to provide data for backpressure estimations. A mercury porosimeter from Micromeretics was used to confirm microstructural filter properties such as porosity and pore size distribution. Macrostructural filter properties such as wall thickness and cell density were confirmed by optical microscopy. The naming convention of samples taken from the filters is included in Fig. 1.

Physical property testing was performed on various filters. The mechanical tests included isostatic strength, shear strength, and modulus of rupture (MOR). Thermal analysis included coefficient of thermal expansion (CTE). These procedures are well described in Heck and Farrauto [3]. The most critical mechanical property for ceramic substrates was isostatic strength. Full-size ceramic filters were tested using a pseudo-3D technique that applied equal, increasing pressure to the entire filter perimeter using a bladder system until breakage occurred (Fig. 2). The test was meant to represent the robustness of the filter to canning, and pressure was not applied to the ends of the filter. The pressure at the point of a break was recorded, and a sample size of at least six to 12 parts of each substrate type was used to provide a valid statistical distribution. The apparatus was located at Watson Engineering in Brownstown, MI.

Full useful life (FUL) aging of full-size TWC and GPF systems was performed on aging dynamometers at Ford and at supplier facilities in southeastern Michigan. A so-called four-mode cycle was used that consisted of stoichiometric, rich, and lean operating modes meant to represent a real life aging of a gasoline three-way catalyst system. A comparison of lambda and temperature for a few typical four-mode cycles is shown in Fig. 3. The 1-min cycles were repeated for 50 to $60 \mathrm{~h}$ on a gasoline engine. Two temperature ranges and two dopant packages were used as described in Table 2.

\section{Results and Discussion}

\subsection{Filtration Efficiency}

In a "no stone unturned" approach, a survey was made of all available ceramic GPFs. Two engine speed/load/lambda points were selected on the 2.0 L GTDI dyno engine: (1) a rich, low speed, moderate temperature point to check for clean filtration efficiency based on particle mass, and (2) a lean, high speed, high temperature point to check clean backpressure. The results of the survey indicated that a wide range of backpressures and clean filtration efficiencies were possible (Fig. 4). Lower porosity
Table 1 Physical properties of ceramic filters included in this study

\begin{tabular}{lllll}
\hline Material & Porosity $(\%)$ & $\begin{array}{l}\text { Mean pore } \\
\text { size }(\mu \mathrm{m})\end{array}$ & $\begin{array}{l}\text { Cell density } \\
\left(\text { cells/in. }{ }^{2}\right.\end{array}$ & $\begin{array}{l}\text { Wall thickness } \\
(\mathrm{mil})\end{array}$ \\
\hline Cordierite & 42 & 14 & 220 & 5 \\
Cordierite & 48 & 12 & 220 & 6 \\
Cordierite & 48 & 12 & 300 & 12 \\
Cordierite & 59 & 14 & 200 & 12 \\
Cordierite & 65 & 20 & 200 & 12 \\
Cordierite & 65 & 20 & 240 & 9.5 \\
Cordierite & 65 & 20 & 240 & 13.5 \\
Cordierite & 65 & 20 & 300 & 8 \\
Cordierite & 65 & 20 & 300 & 12 \\
\hline
\end{tabular}




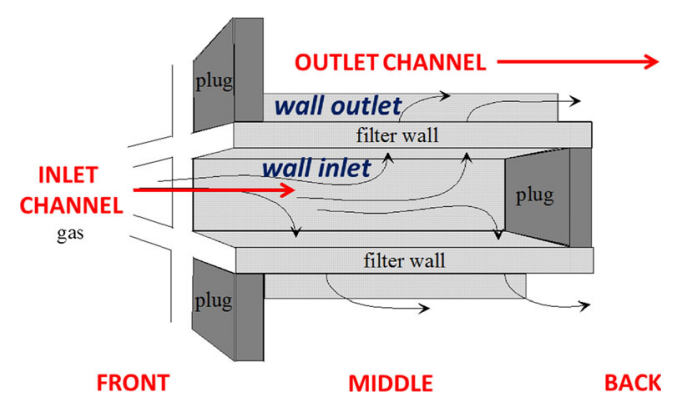

Fig. 1 Nomenclature used for sample locations within a GPF

ceramic options $(<60 \%)$, especially with washcoat and ash deposition from engine dynamometer aging, exhibited the highest backpressures and filtration efficiencies. Higher porosity $(>60 \%)$ ceramic options tended to have lowest backpressure before and after aging. It is important to note that the aging was not intended to result in a full useful life amount of ash; rather, a small amount of ash was deposited as a result of lubricant-based fuel additives meant to poison the three-way catalyst. The agings with ZDDP and $\mathrm{Ca}$ sulfonate resulted in less than $3 \mathrm{~g}$ of total ash, while the agings with the organophosphate left only about a gram of ash total. Nonetheless, these small amounts of ash resulted in improved filtration efficiency.

The low clean filtration of the fresh clean filters was both a surprise and a major concern. It is the soot cake in a diesel particle filter that results in 99+\% filtration, and GPFs with passive operation were not expected to have soot cake buildup. However, a small amount of soot less than $0.03 \mathrm{~g}$ was found to improve filtration to $90 \%$ (Fig. 5). Later, it was found that small amounts of ash also improved filtration to over $80 \%$ (Fig. 6). The 50-h dyno-aged filter contained less than $3 \mathrm{~g}$ of ash while the $3000 \mathrm{~km}$ filter contained about $1 \mathrm{~g}$ of ash. These small improvements alleviated the initial concerns on filtration.

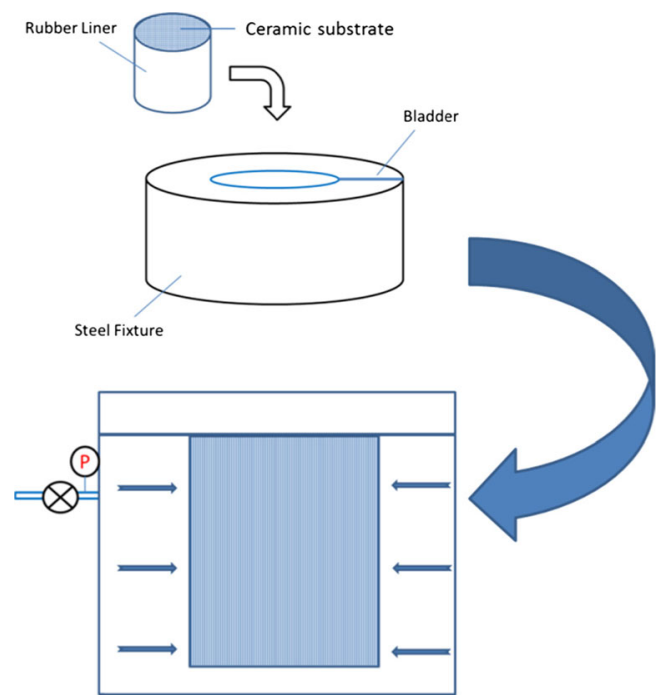

Fig. 2 Apparatus used to measure isostatic strength of ceramic catalyst and filter substrates

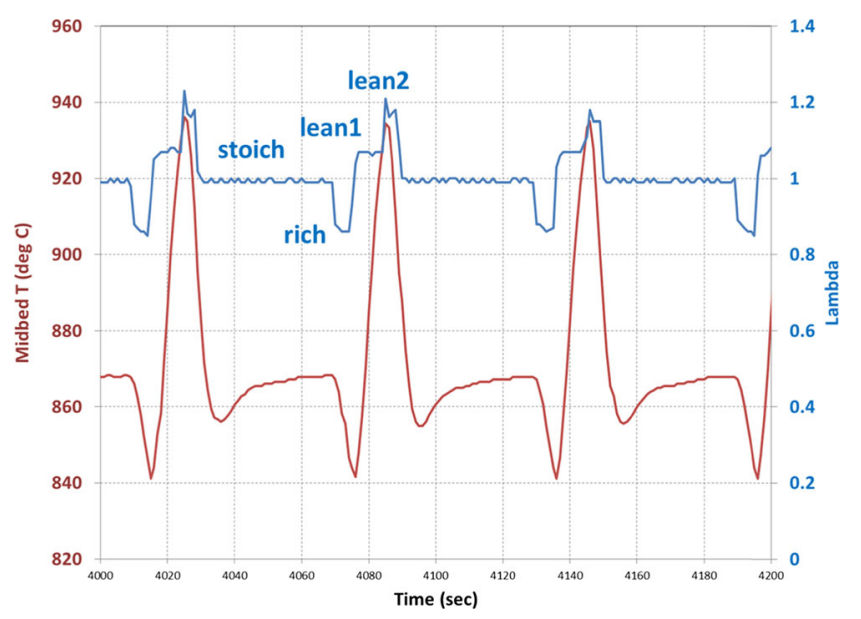

Fig. 3 Exhaust temperature and air/fuel ratio (lambda) trace during a four-mode aging cycle on engine with a TWC+GPF system. The temperature was measured between the TWC and the GPF. The cycles were $1 \mathrm{~min}$ each and repeated for 50 to $60 \mathrm{~h}$

\subsection{Full Useful Life Impacts}

A high-mileage GPF study was conducted [4]. A total of $60 \mathrm{~g}$ of non-combustible material was trapped over $150,000 \mathrm{mi}$ (full useful life) on a 3.5-L GTDI vehicle. The ash types found in the vehicle filter were approximately $50 \%$ engine oil additive components (Ca, P, S, Zn), 20\% corrosion material (mainly $\mathrm{Fe}_{2} \mathrm{O}_{3}$ ), and $30 \%$ catalytic washcoat that apparently eroded off the three-way catalysts located upstream of the filter. The capture efficiency of engine oil components was calculated to be about $50 \%$, and the capture rate of corrosion material, mainly $\mathrm{Fe}_{2} \mathrm{O}_{3}$, was $0.6-0.8 \mathrm{~g} / 10,000 \mathrm{mi}$. The catalytic material caught from upstream catalysts represented approximately $5 \%$ washcoat loss and was within specifications. The system backpressure measured at $80 \mathrm{mph}$ increased from about 3 to $6.5 \mathrm{kPa}$, and no impact on fuel economy was measurable. This was surprising given the observation that two thirds of the ash was along the filter walls, effectively lowering the wall permeability by $75 \%$. Only one third of the ash was located in the plug region at the back of the filter.

Rapid ash loading was conducted to FUL levels using a gasoline burner at MIT [5]. The resulting filters duplicated the findings of the high-mileage study noted above, although the ash was composed mainly of engine oil additives due to the nature of the rapid aging process. It was found that the pressure responses of ash and soot were not the same, and roughly $10 \mathrm{~g}$ of ash gave a pressure increase equal to about $1 \mathrm{~g}$ of soot.

\subsection{Washcoat Loading}

A washcoat loading study was done on high-porosity $(>60 \%)$ cordierite filters to check if the clean filtration efficiency could be improved. Three loading ranges were chosen (low, mid, and high). The high washcoat loading 
Table 2 Specifications for exhaust temperature, duration, and fuel dopants for two types of four-mode cycles

\begin{tabular}{llll}
\hline Four-mode cycle designation & $\begin{array}{l}\text { Exhaust temperature } \\
\text { range }\left({ }^{\circ} \mathrm{C}\right)\end{array}$ & $\begin{array}{l}\text { Duration } \\
(\mathrm{h})\end{array}$ & Dopant package \\
\hline A & $970-1040$ & 50 & Zn dialkyl-dithiophosphate, Ca sulfonate \\
B & $840-930$ & 60 & Organophosphate \\
\hline
\end{tabular}

level corresponded to the typical loading on a flowthrough three-way catalyst in production. Low was about $25-30 \%$ of the high level, and mid was about $50 \%$. The full-size filters were tested on the engine dynamometer at the two operating conditions used previously: (1) a rich, low speed, moderate temperature point to check for clean filtration efficiency based on particle mass, and (2) a lean, high speed, high temperature point to check clean backpressure. The results in Fig. 7 indicated that no more than a mid-level washcoat loading was tolerable while maintaining acceptable backpressure. When testing high levels, attempts to run $600 \mathrm{~kg} / \mathrm{h}$ exhaust flow failed, and only $300-400 \mathrm{~kg} / \mathrm{h}$ was possible before warning lights indicated a high manifold pressure. The experiment was stopped at these lower flows to prevent damage to the engine. Note that even at the lower flows, the backpressure approached $100 \mathrm{kPa}$ for the high loadings. It was also noted that a low-level coated filter that was run for $3000 \mathrm{~km}$ on road contained enough ash to improve the filtration efficiency to nearly $80 \%$ at much lower pressures. Therefore, the approach of very high washcoat loadings was abandoned.

Curiously, it was also noticed that some washcoated filters had lower filtration efficiency than the blank filters. After investigating with microscopy, porosimetry, and cold flow, it was determined that sometimes the coating can result in a reduced pore volume, higher pore velocity, and lower filtration efficiency than a blank filter.

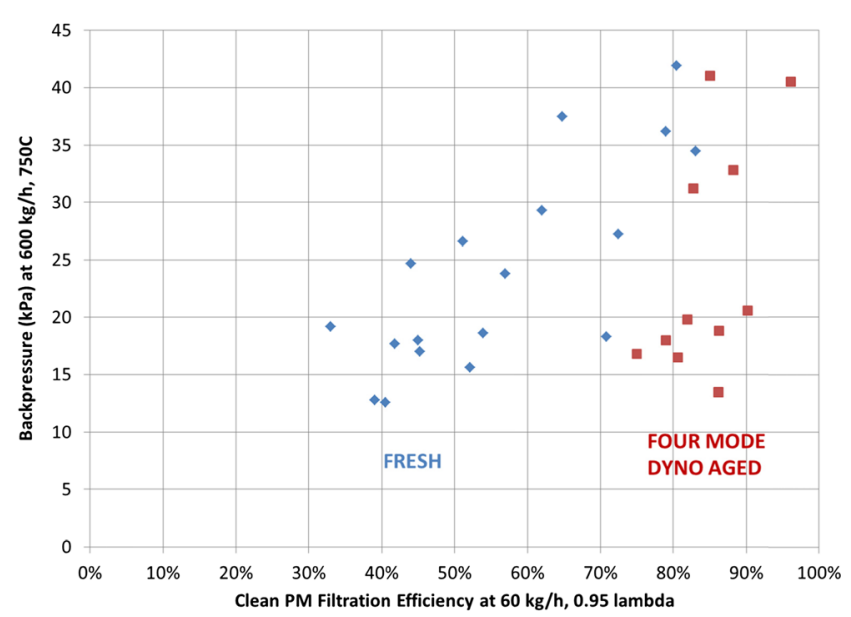

Fig. 4 Clean (initial) filtration efficiencies and backpressures of a variety of ceramic GPFs

\subsection{Filtration and Backpressure Models}

A filtration efficiency model of wall flow ceramic media was established based on single collector model proposed by Konstandopoulos. Details of the modeling can be found elsewhere [6]. Briefly, the ceramics filter was characterized by a single spherical collector with a diameter depending on the pore size and porosity of ceramic walls. Semi-empirical equations were used to calculate the efficiency of diffusion, interception, and inertial impaction respectively and determine the filtration efficiency of a single collector. The filtration efficiency of the ceramic media was further calculated considering collections of the single collectors. The model took into account temperature, flow rate, particle size distribution, filter geometry, cell density, wall thickness, characteristic pore size, and porosity. The model includes diffusion, interception, and impaction mechanisms of particle filtration (Fig. 8). An example of the model output is below in Fig. 9. The calculated filtration efficiencies for a variety of coated and blank GPFs was comparable to the measured filtration efficiencies on the engine dynamometer at approximately $500{ }^{\circ} \mathrm{C}$ and $60 \mathrm{~kg} / \mathrm{h}$. The calculated results agreed with the measured data even in the cases of washcoated filters with lower filtration than similar, blank filters.

A backpressure model was developed that included the backpressure of the filter wall, the channel pressure loss,

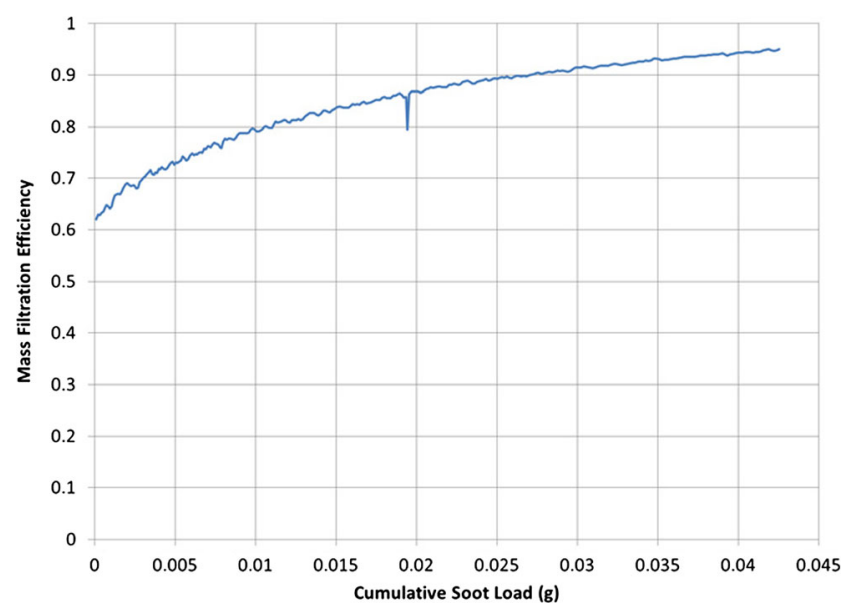

Fig. 5 Improvement in particle mass filtration efficiency with increasing soot load on a ceramic GPF $\left(5.66\right.$ " $\times 4$ " sample, 300 cells/in. ${ }^{2}, 12 \mathrm{mil}$ walls, $65 \%$ porosity, $1 \mathrm{~g} / \mathrm{in}^{3}{ }^{3}$ washcoat, $60 \mathrm{~kg} / \mathrm{h}$ flow) 


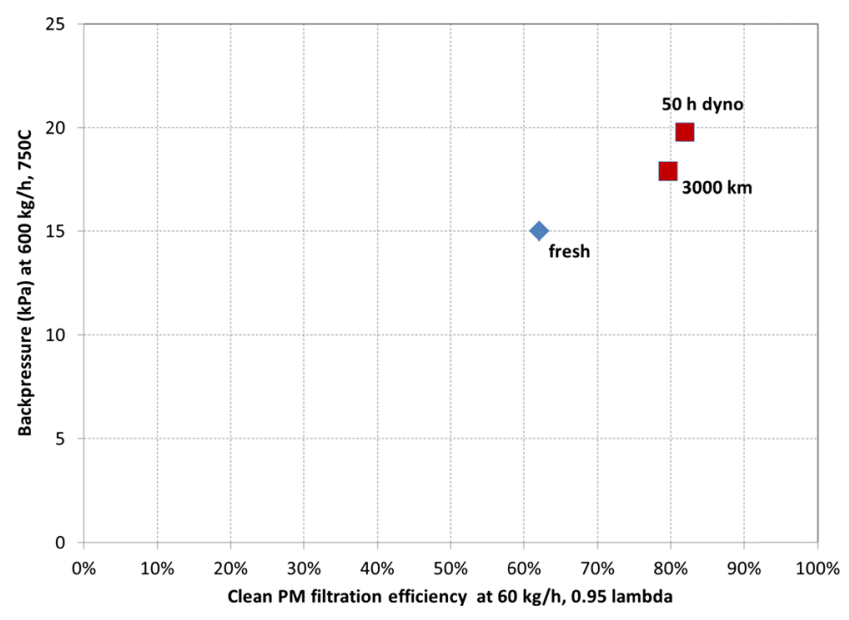

Fig. 6 Comparison of backpressure and clean filtration efficiency of a fresh filter vs. similar filters exposed to either $50 \mathrm{~h}$ of dyno aging with ZDDP and Ca sulfonate dopants or $3000 \mathrm{~km}$ of onroad mileage

and the contraction and expansion of the filter inlet and outlet [4]. The wall loss term was based on Darcy's Law, the channel losses were based on the Poiseuille Equation, and the inlet/exit effects were based on the Borda-Carnot Equation. The permeability of the filter wall was reduced if a layer of ash was present. Clean wall permeabilities typically ranged from $0.1 \mu \mathrm{m}^{2}$ for a low porosity filter to a high of $4 \mu \mathrm{m}^{2}$ for a filter with a high useful porosity. Addition of an ash layer reduced the wall permeability by $75 \%$ in a high-mileage $(150,000 \mathrm{mi})$ example [4]. However, the overall backpressure of the system only increased a few kilopascals at an $80 \mathrm{mph}$ speed point.

The overall backpressure of a high porosity GPF was estimated at a more extreme rated power condition of $975 \mathrm{~kg} / \mathrm{h}$ exhaust flow and $850{ }^{\circ} \mathrm{C}$. This condition would be performed to estimate the peak engine horsepower. The filter exit pressure was assumed to be about $50 \mathrm{kPa}$ gauge

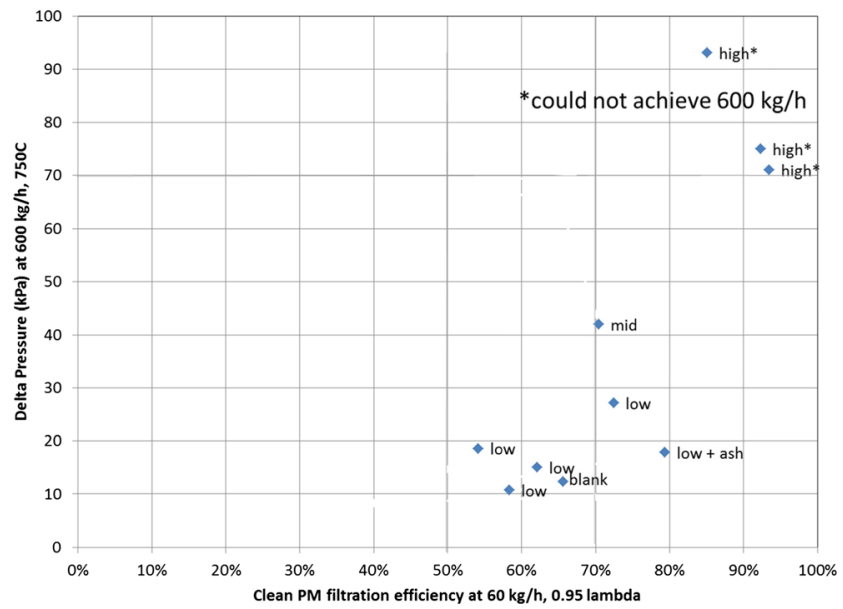

Fig. 7 Impact of low, mid, and high washcoat loadings on similar ceramic GPFs

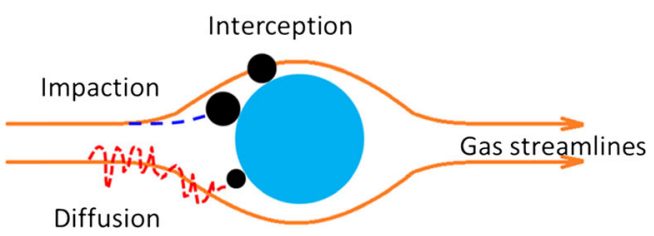

Fig. 8 Schematic of filtration mechanisms for particles in a GPF

due to downstream exhaust components including the resonator and muffler. The backpressure model was exercised for several filter parameters including wall permeability, cell density, wall thickness, filter length, filter diameter, and addition of soot and ash. The results are summarized in Table 3. Each change to the filter resulted in ever higher backpressure. For the relatively high permeabilities used, the contribution from channel friction was higher than from wall flow when the walls were clean, so increasing length increased overall pressure drop. There was an optimum length which depended on the balance between friction and wall flow resistance; this optimum length increased with decreasing permeability. If the wall permeability had been significantly lower, the fraction of backpressure related to the wall loss vs. the channel loss would have been different. The balance of wall loss vs. channel loss was not affected by diameter. Reducing diameter increased both contributions proportionately. The contribution of wall permeability was relatively minor compared to filter geometry and the addition of soot + ash. This suggested that when soot and ash were taken into account, increasing total filter wall flow area (by increasing volume) was, in most cases, more important than reducing filter wall substrate permeability.

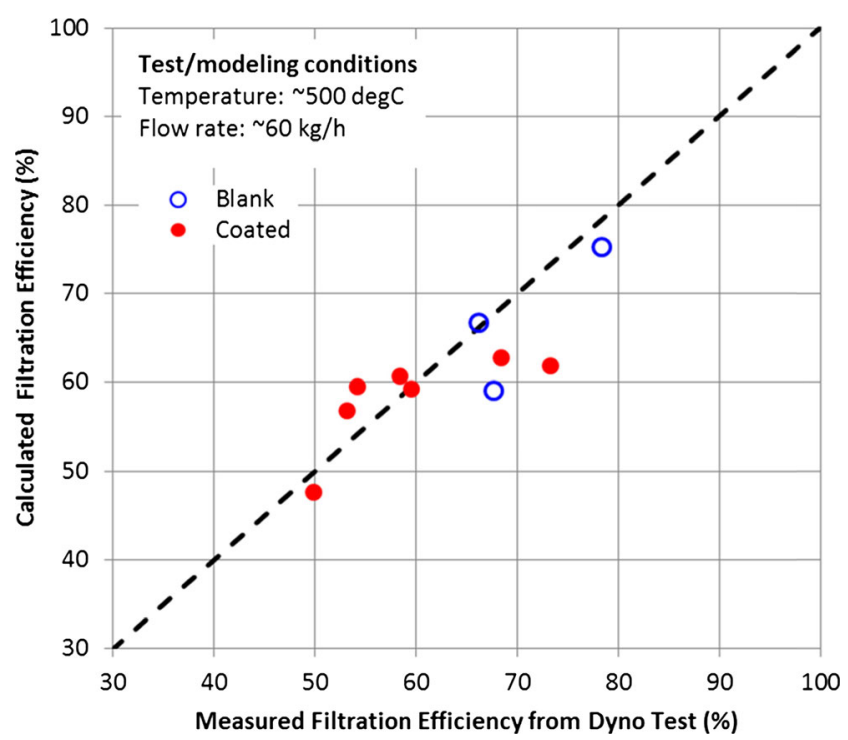

Fig. 9 Model estimates vs. measured filtration efficiencies for blank and washcoated GPFs 
Table 3 Estimated backpressures of a GPF with changing filter wall permeability, cell density, wall thickness, length, diameter, soot load, and ash load

\begin{tabular}{|c|c|c|c|c|c|c|c|c|}
\hline & dia (in.) & Length (in.) & cpsi & Wall (mil) & $k\left(\mu \mathrm{m}^{2}\right)$ & Soot $(\mathrm{g} / \mathrm{L})$ & Ash (g) & Delta $\mathrm{P}(\mathrm{kPa})$ \\
\hline & 5.66 & 4 & 300 & 8 & 2 & 0 & 0 & 10.8 \\
\hline$<\mathrm{k}$ & 5.66 & 4 & 300 & 8 & 1 & 0 & 0 & 12.4 \\
\hline <cpsi, >wall & 5.66 & 4 & 200 & 12 & 1 & 0 & 0 & 14.7 \\
\hline$>$ cpsi & 5.66 & 4 & 300 & 12 & 1 & 0 & 0 & 18.0 \\
\hline$>\mathrm{L}$ & 5.66 & 5 & 300 & 12 & 1 & 0 & 0 & 18.7 \\
\hline$>\mathrm{L}$ & 5.66 & 6 & 300 & 12 & 1 & 0 & 0 & 19.9 \\
\hline$<\mathrm{L},<$ dia & 5.2 & 4 & 300 & 12 & 1 & 0 & 0 & 22.4 \\
\hline$<\mathrm{k}$ & 5.2 & 4 & 300 & 12 & 0.5 & 0 & 0 & 28.3 \\
\hline +soot & 5.2 & 4 & 300 & 12 & 0.5 & 2 & 0 & 43.9 \\
\hline +ash & 5.2 & 4 & 300 & 12 & 0.5 & 2 & 20 & 50.4 \\
\hline$<\mathrm{dia},>\mathrm{L}$ & 4.66 & 5 & 300 & 12 & 0.5 & 2 & 20 & 58.0 \\
\hline
\end{tabular}

A flow condition of $850^{\circ} \mathrm{C}$ and $975 \mathrm{~kg} / \mathrm{h}$ was used

dia diameter, cpsi cells per square inch, $k$ permeability, $L$ length

\subsection{Filter Mechanical Properties and Robustness}

Filters have mechanical durability requirements to survive installation and full useful life on a vehicle. The key parameters in this study were:

- Isostatic - robustness to canning

- Shear - uneven canning stress

- MOR - bending strength

- CTE-thermal expansion

- Creep - deformation at high T and P

Isostatic strength testing was performed on a variety of filters. The target for canning robustness was set at $1.0 \mathrm{MPa}$, a Ford Corporate Standard. This was met by the most fragile flow-through brick in use today, the 900/2 TWC used as the first brick in many gasoline emission control systems

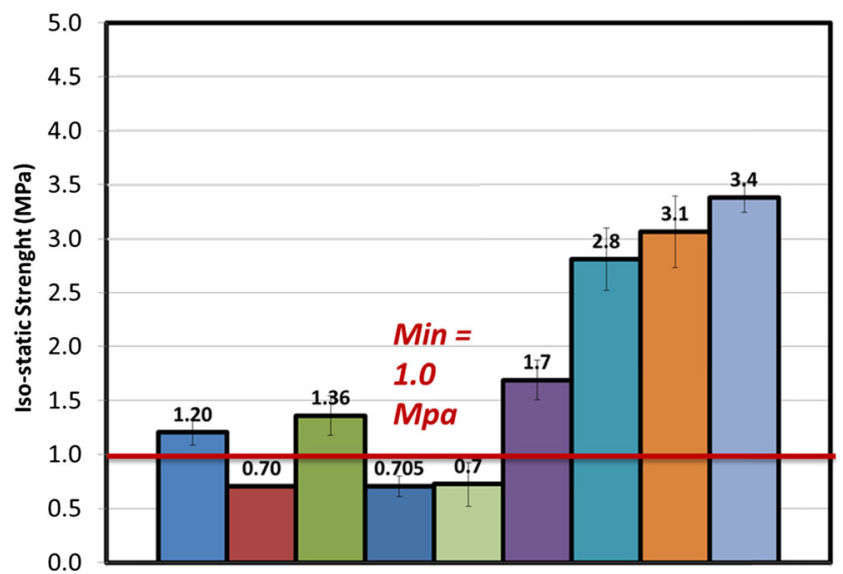

Fig. 10 Results of isostatic strength testing of full-size GPFs. A sample set of at least six filters of each type was used
(Fig. 10). A few filter types did not meet the target and were not considered further.

Shear strength represented potential substrate failure under uneven canning conditions. Maximum shear was at $45^{\circ}$ to the compression axis. Shear strength of several prototype ceramic GPFs was measured. Lower shear strength tended to occur at higher porosities, lower cell densities, and thinner walls. Catalytic washcoat improved shear strength only marginally. Ceramics can fail under tension, and flexural strength was determined by a modulus of rupture (MOR) 4-point bending test at room temperature (ASTM C1674). Thermal expansion was another important mechanical property, especially if washcoat distribution is potentially uneven or zoning is done intentionally. Results from MOR and CTE measurements were not of much concern. A more relevant test, especially for parts with catalytic washcoat, was the creep test. Creep represents stress at high temperatures. The sample was placed in an oven under 2 psi load from 850 to $1350^{\circ} \mathrm{C}$ in increments of $50{ }^{\circ} \mathrm{C}$. The point of sample deformation was noted in a blank cordierite sample at about $1350{ }^{\circ} \mathrm{C}$, and the addition of catalytic washcoat appeared to accelerate the deformation at lower temperatures (Fig. 11).
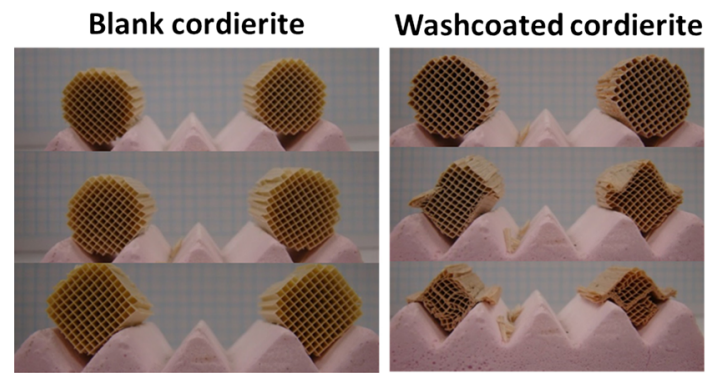

$1250^{\circ} \mathrm{C}$

$1300^{\circ} \mathrm{C}$

$1350^{\circ} \mathrm{C}$

Fig. 11 Results of creep test at various temperatures for blank and washcoated cordierite 


\subsection{Physical Dimensions}

It was found during the course of GPF development that data often did not match estimates and expectations. Therefore, it became important to check pertinent physical dimensions, including the following:

- Porosity and mean pore size (Hg porosimetry)

- Wall thickness (optical microscopy)

- Cell density (optical microscopy)

- Washcoat distribution (core section weights)

- Plug length (micrometer)

Finally, filters sometimes needed to be inspected for defects, like edge chips that can cause leaks. Missing or incomplete plugs were sometimes found. The extra time taken to do actual measurements and visually inspect filters was invaluable to explain experimental data that could otherwise not be explained.

\section{Conclusions}

The following conclusions were found during GPF development:

- GPFs did not operate like DPFs, yet requirements for low backpressure and high filtration were similar.

- GPF design space was found to be large with a wide range of filtration efficiencies and backpressures.

- Initial filtration efficiency was improved by:

- $0.1 \mathrm{~g}$ soot

- $1 \mathrm{~g}$ ash

- High washcoat loading (not recommended)

- A fundamental model was used to predict steady-state filtration efficiencies of blank and washcoated filters with reasonable agreement.
- Full-size GPF backpressures were predicted from Darcy's Law, Poiseuille's Law, and Borda-Carnot equation; wall permeability was not a dominant parameter relative to filter geometry and the addition of soot and/or ash.

- GPF physical dimensions and integrity may need to be confirmed through actual measurements and inspections.

- GPF mechanical properties were important, esp. isostatic strength, shear strength, and creep.

Acknowledgements The author acknowledges the Ford team efforts, especially those of Mira Bumbaroska, Jon Hangas, Jeong Kim, Paul Tennison, Justin Ura, and James Warner. Rapid ash loading via a burner was performed at MIT under the direction of Prof. Wong. Work at MIT was performed under the direction of Prof. Wong and funded by Ford Motor Company.

\section{Compliance with Ethical Standards}

Conflict of Interest The authors declare that they have no competing interests.

\section{References}

1. Chan, T.W., Meloche, E., Kubsh, J., Rosenblatt, D., Brezny, R., Rideout, G.: Evaluation of a gasoline particulate filter to reduce particle emissions from a gasoline direct injection vehicle. SAE Technical Paper 2012-01-1727

2. Heck, R.M., Farrauto, R.J., Gulati, S.T.: Catalytic air pollution control: commercial technology, 3rd edn. Wiley, Hoboken (2009)

3. Maricq, M.M., Szente, J.J., Adams, J., Tennison, P., Rumpsa, T.: Influence of mileage accumulation on the particle mass and number emissions of two gasoline direct injection vehicles. Environ. Sci. Technol. 47, 11890-11896 (2013)

4. Bumbaroska, M., Dobson, D., Hangas, J., Pakko, J., Lambert, C., Tennison, P.: Analysis of high mileage gasoline exhaust particle filters. SAE Technical Paper 2016-01-0941

5. Custer, N., Kamp, C.J., Sappok, A., Pakko, J., Lambert, C., Boerensen, C., Wong, V.: Lubricant-derived ash impact on gasoline particulate filter performance. SAE Technical Paper 2016-01-0942

6. Konstandopoulos, A.G., Johnson, J.: Wall-flow diesel particulate filters-their pressure drop and collection efficiency. SAE Technical Paper 890405, 1989 doi: 10.4271/890405 